\title{
Reframing the 'Everything is everywhere' debate: evidence for high gene flow and diversity in ciliate morphospecies
}

\author{
Laura A. Katz ${ }^{1,2, *}$, George B. McManus ${ }^{3}$, Oona L. O. Snoeyenbos-West ${ }^{1,5}$, \\ Autumn Griffin ${ }^{1}$, Katarzyna Pirog ${ }^{1}$, Barbara Costas ${ }^{3}$, Wilhelm Foissner ${ }^{4}$ \\ ${ }^{1}$ Department of Biological Sciences, Smith College, College Road, Northampton, Massachusetts 01063, USA \\ ${ }^{2}$ Program in Organismic and Evolutionary Biology, University of Massachusetts-Amherst, 611 N. Pleasant Street, Amherst, \\ Massachusetts 01003, USA \\ ${ }^{3}$ Department of Marine Sciences, University of Connecticut, 1080 Shennecossett Rd., Groton, Connecticut 06340, USA \\ ${ }^{4}$ Institut für Zoologie, Universität Salzburg, Hellbrunnerstr. 34, 5020 Salzburg, Austria \\ ${ }^{5}$ Present address: Dept of Plant, Soil and Insect Sciences, Fernald Hall, UMASS Amherst, Amherst, Massachusetts 01003, USA
}

\begin{abstract}
Current debate on microbial diversity contrasts the 'cosmopolitan' hypothesis, which argues for high gene flow and low diversity, with the 'endemism' hypothesis, which argues for high diversity and geographically restricted gene flow. Our analyses of genetic variation in ciliate morphospecies isolated from ephemeral environments (freshwater ponds and tide pools) redefine this debate. In 2 different clades of oligotrich ciliates (in the genera Halteria/Meseres and Strombidium), we found both high levels of diversity and evidence of high gene flow as indicated by the presence of identical haplotypes across broad geographic ranges. Five recognizable morphospecies of Halteria/Meseres were found to be composed of 7 different clades, differing by as much as $7.6 \%$ sequence divergence at the ITS locus (ITS1, ITS2 and 5.8S rDNA). Two recognizable morphospecies of Strombidium ( $S$. oculatum and $S$. stylifer) resolved into 10 distinct clades, differing by as much as $15.7 \%$ at the same locus. For both groups of ciliates, the genetic divergence underlying these morphospecies may be related to cycles of isolation in their ephemeral habitats (freshwater lakes and ponds for Halteria/Meseres and tide pools for Strombidium). By comparison, there is both low diversity and high gene flow in published data on ciliates from open coastal water (Laboea strobila and several species of tintinnids), a more stable environment over evolutionary time-scales. Our analyses indicate that models of microbial diversity must test for ecologically driven patterns in the interactions of gene flow and species richness to account for observed patterns of high dispersal and high gene flow.
\end{abstract}

KEY WORDS: Ciliate phylogeography $\cdot$ Endemism $\cdot$ Cosmopolitanism $\cdot$ Gene flow $\cdot$ Cryptic species

Resale or republication not permitted without written consent of the publisher

\section{INTRODUCTION}

Recent discussions on ciliate biogeography reflect 2 schools of thought in the broader debate on the phylogeography of eukaryotic microbes (protists). The first maintains that all microbes, including ciliates, have cosmopolitan distributions, with a low degree of endemism and low species numbers (Finlay et al. 1996a,b, Fenchel et al. 1997). Proponents of this view argue that microbial species are characterized by large population sizes and, hence, high dispersal probability, which prevents isolation and allopatric speciation. In support of this view, Fenchel et al. (1997) found that approximately $8 \%$ of all described, free-living ciliate morphospecies were present in core samples representing less than $50 \mathrm{~cm}^{2}$ total of sediment from a single small lake and a shallow marine bay. They concluded that 'in the case of microorganisms... global species diversity is relatively limited' (Fenchel et al. 1997). An opposing school of thought holds that fewer than half of the exist- 
ing species of ciliates have been described and posits a greater degree of endemism in ciliate species (Foissner 1998, 1999). Evidence in support of this includes the observation of apparently geographically limited 'flagship species' and the continued high rate of new morphospecies descriptions (Foissner 1997, in press).

To evaluate these hypotheses, we characterized DNA polymorphisms at the internally transcribed spacer regions (ITS) of the rDNA locus (ITS1, 5.8S rDNA, ITS2) in 2 clusters of morphospecies isolated from ephemeral environments: the freshwater species Halteria grandinella and several close relatives (Spirotrichea: Oligotrichia), and the marine tide pool species Strombidium oculatum and S. stylifer (Spirotrichea: Oligotrichia). We also compared patterns of variation from these ciliates to those of related planktonic morphospecies, including previously published sequences of Eutintinnus pectinis, Tintinnopsis sp. and Favella ehrenbergii, and Laboea strobila (Spirotrichea: Choreotrichia) (SnoeyenbosWest et al. 2002, Agatha et al. 2004). Our collection sites included places in North America, South America, Africa, and Europe.

\section{MATERIALS AND METHODS}

Ciliates were either picked directly from natural populations (all of the Strombidium oculatum samples) or cultured in the laboratory before characterization of individual clones (most $S$. stylifer and Halteria spp. samples; Tables 1 \& 2). Samples of $H$. grandinella, 3 distinct undescribed Halteria spp. and the closely related Meseres corlissi were collected from 13 sites, and in many cases clonal lines were generated by passing single cells through several washes (Table 1). No substantial differences were seen in genetic variation (ITS locus) in Halteria spp. samples from clonal lines compared to those from natural populations (data not shown). We also include previously published sequences from Massachusetts population 1 and Colorado in our analyses (Table 1). Most Halteria populations were characterized morphologically and morphometrically using protargol impregnation and scanning electron microscopy (Foissner 1991).

We collected 25 samples of Strombidium oculatum and S. stylifer from populations located along the

Table 1. Populations of Halteria grandinella and its relatives. Clade numbers refer to Fig. 1

\begin{tabular}{|c|c|c|c|c|c|c|c|}
\hline Morphospecies & Sample location & Latitude & Longitude & $\begin{array}{l}\text { Date } \\
\text { isolated }\end{array}$ & $\begin{array}{l}\text { Clonal } \\
\text { line }\end{array}$ & $\begin{array}{l}\text { No. of } \\
\text { clones }\end{array}$ & Clade \\
\hline H. grandinella & Freshwater pond off I-90 near Missoula, MT & $47^{\circ} 09^{\prime} \mathrm{N}$ & $114^{\circ} 50^{\prime} \mathrm{W}$ & Jun 02 & Yes & 6 & 1 \\
\hline H. grandinella & $\begin{array}{l}\text { Freshwater pond off Willcutt Road in Chesterfield, } \\
\text { MA }_{i}(\text { MA 2) }\end{array}$ & $42^{\circ} 1^{\prime} \mathrm{N}$ & $72^{\circ} 50^{\prime} \mathrm{W}$ & Jul 04 & No & 14 & 1 \\
\hline H. grandinella & $\begin{array}{l}\text { Freshwater pond (Meekin Brook) rte-143W } \\
\text { Chesterfield, MA; (MA 3) }\end{array}$ & $42^{\circ} 23^{\prime} \mathrm{N}$ & $72^{\circ} 46^{\prime \prime} \mathrm{W}$ & Jul 04 & No & 8 & 1 \\
\hline H. grandinella & $\begin{array}{l}\text { Freshwater pond (Meekin Brook) rte-143W } \\
\text { Chesterfield, MA; (MA 4) }\end{array}$ & $42^{\circ} 23^{\prime} \mathrm{N}$ & $72^{\circ} 46^{\prime} \mathrm{W}$ & Jul 04 & No & 6 & 1 \\
\hline H. grandinella & Freshwater pond in Lory State Park, Bellevue, CO & $40^{\circ} 34^{\prime} \mathrm{N}$ & $105^{\circ} 10^{\prime} \mathrm{W}$ & Jun 04 & No & 1 & 2 \\
\hline H. grandinella & $\begin{array}{l}\text { Freshwater pond, Botanical Gardens, } \\
\text { Univ Puerto Rico, Rio Piedras }\end{array}$ & $18^{\circ} 23^{\prime} \mathrm{N}$ & $66^{\circ} 2^{\prime} \mathrm{W}$ & Jan 03 & Yes & 8 & 2 \\
\hline H. grandinella & $\begin{array}{l}\text { Freshwater pond, Harbour Branch Ocean Station, } \\
\text { Ft. Pierce, FL }\end{array}$ & $27^{\circ} 22^{\prime} \mathrm{N}$ & $80^{\circ} 19^{\prime} \mathrm{W}$ & Jul 02 & Yes & 4 & 2 \\
\hline H. grandinella & $\begin{array}{l}\text { Freshwater pond, San Francisco Botanical Gardens, } \\
\text { San Francisco, CA }\end{array}$ & $37^{\circ} 46^{\prime} \mathrm{N}$ & $112^{\circ} 24^{\prime} \mathrm{W}$ & Jul 03 & Yes & 6 & 3 \\
\hline H. grandinella & Simmelried bog near Constance, Germany & $47^{\circ} 40^{\prime} \mathrm{N}$ & $9^{\circ} 05^{\prime} \mathrm{E}$ & Aug 04 & Yes & 2 & 3 \\
\hline H. grandinella & Zicklacke (alkaline lake) near Vienna, Austria & $47^{\circ} 45^{\prime} \mathrm{N}$ & $16^{\circ} 50^{\prime} \mathrm{E}$ & Aug 04 & Yes & 3 & 3 \\
\hline H. grandinella & $\begin{array}{l}\text { Tank bromeliad in the Tiputini Biodiversity Station, } \\
\text { Coca, Ecuador }\end{array}$ & $0^{\circ} 27^{\prime} \mathrm{S}$ & $76^{\circ} 59^{\prime} \mathrm{W}$ & Jun 04 & No & 14 & 2 \\
\hline Halteria sp. & Mangrove swamp (slightly saline), Dominican Republic & $19^{\circ} \mathrm{N}$ & $70^{\circ} \mathrm{W}$ & Jun 02 & No & 2 & 7 \\
\hline Halteria sp. & Floodplain soil from the Chobe River, Botswana, Africa & $23^{\circ} \mathrm{S}$ & $21^{\circ} \mathrm{E}$ & Aug 04 & No & 5 & 5 \\
\hline Halteria sp. & $\begin{array}{l}\text { Floodplain soil from the Panará River } \\
\text { near town of Maringa, Brazil }\end{array}$ & $22^{\circ} 40^{\prime} \mathrm{S}$ & $53^{\circ} 15^{\prime} \mathrm{W}$ & Jun 02 & No & 3 & 6 \\
\hline Meseres corlissi & $\begin{array}{l}\text { Floodplain soil from the Panara River } \\
\text { near town of Maringa, Brazil }\end{array}$ & $22^{\circ} 40^{\prime} \mathrm{S}$ & $53^{\circ} 15^{\prime} \mathrm{W}$ & Jun 02 & No & 2 & 4 \\
\hline H. grandinella & $\begin{array}{l}\text { Pond University of Colorado Campus, Boulder, } \\
\text { CO, GB\#AF508759 }\end{array}$ & \multicolumn{2}{|c|}{ From GenBank } & & & 1 & 1 \\
\hline H. grandinella & $\begin{array}{l}\text { Smith College Greenhouse Pond, Northampton, } \\
\text { MA, GB\#AY007444 }\end{array}$ & \multicolumn{2}{|c|}{ From GenBank } & & & 6 & 3 \\
\hline
\end{tabular}


coasts of New England, Ireland, the Isle of Man (British Isles), and Brazil (Table 2). The Strombidium samples were collected over short temporal and spatial scales (consecutive low tides and adjacent pools) in order to assess intrapopulation diversity. With the exception of populations of $S$. stylifer from Connecticut, no clonal lines were generated for these taxa. In fact, none of the $S$. oculatum could be maintained in cultures and hence all data on this taxon are from field collections.
Nucleic acid extraction and amplification were performed according to the protocol described in Snoeyenbos-West et al. (2002). PCR reactions were run in the Peltier Thermal Cycler (PTC-200) under the same conditions as those described in SnoeyenbosWest et al. (2002). Cloning was performed using the TOPO TA Cloning Kit (Invitrogen \#45-0641). Direct sequencing of PCR products from cloned plasmid DNA was accomplished in the forward direction using gene-

Table 2. Strombidium oculatum and S. stylifer populations. Clade numbers refer to Fig. 3. All S. oculatum samples were picked from natural populations; all $S$. stylifer populations were from clonal cultures, except Cove Island Park, Connecticut, 27 September 2002, and Brazil. ANP = Acadia National Park in Bar Harbor, ME; SML = Shoals Marine Lab, Appledore Island, ME

\begin{tabular}{|c|c|c|c|c|c|}
\hline $\begin{array}{l}\text { Morpho- } \\
\text { species }\end{array}$ & $\begin{array}{c}\text { Sample location } \\
(\sim \text { distance from Pool 1) }\end{array}$ & $\begin{array}{l}\text { Date } \\
\text { isolated }\end{array}$ & $\begin{array}{l}\text { Total no. } \\
\text { of clones }\end{array}$ & Clade & $\begin{array}{l}\text { Clones per } \\
\text { clade }\end{array}$ \\
\hline S. oculatum & Dublin Bay, Pool $1^{\mathrm{a}}(0 \mathrm{~m})$, AM low tide & 14 May 02 & 3 & $\begin{array}{l}\text { II } \\
\text { III }\end{array}$ & $\begin{array}{l}2 \\
1\end{array}$ \\
\hline S. oculatum & Dublin Bay, Pool 2 (5 m), AM low tide & 14 May 02 & 4 & IV & 4 \\
\hline S. oculatum & Dublin Bay, Pool 4 (5 m), AM low tide & 14 May 02 & 58 & $\begin{array}{c}\text { VIII } \\
\text { V } \\
\text { IV } \\
\text { X } \\
\text { IX }\end{array}$ & $\begin{array}{c}19 \\
1 \\
34 \\
2 \\
2\end{array}$ \\
\hline S. oculatum & Dublin Bay, Pool 6 (5 m), AM low tide & 14 May 02 & 3 & IV & 3 \\
\hline S. oculatum & Dublin Bay, Pool T (10 m), AM low tide & 14 May 02 & 2 & II & 2 \\
\hline S. oculatum & Dublin Bay, Pool 1 (0 m), PM low tide & 14 May 02 & 2 & $\begin{array}{c}\text { IV } \\
\text { I }\end{array}$ & $\begin{array}{l}1 \\
1\end{array}$ \\
\hline S. oculatum & Dublin Bay, Pool 4 (5 m), PM low tide & 14 May 02 & 66 & $\begin{array}{c}\text { VIII } \\
\text { IV } \\
\text { II } \\
\text { IX }\end{array}$ & $\begin{array}{c}60 \\
3 \\
2 \\
1\end{array}$ \\
\hline S. oculatum & Dublin Bay, Pool T (10 m), PM low tide & 14 May 02 & 4 & $\begin{array}{l}\text { VIII } \\
\text { II }\end{array}$ & $\begin{array}{l}2 \\
2\end{array}$ \\
\hline S. oculatum & Dublin Bay, Pool 13 (3.7 km), AM low tide & 11 Jun 02 & 3 & IV & 3 \\
\hline S. oculatum & Dublin Bay, Pool 13 (3.7 km), PM low tide & 10 Jun 02 & 6 & $\begin{array}{l}\text { IV } \\
\text { II }\end{array}$ & $\begin{array}{l}2 \\
4\end{array}$ \\
\hline S. oculatum & Dublin Bay, Pool 1 (0 m) & 6 Jun 02 & 8 & II & 8 \\
\hline S. oculatum & Dublin Bay, Pool 4 (5 m) & 9 Apr 02 & 2 & IV & 2 \\
\hline S. oculatum & Dublin Bay, Pool 9 (1 km) & 23 Apr 02 & 9 & IV & 9 \\
\hline S. oculatum & Galway Bay (220 km) & 25 Jun 02 & 44 & II & 44 \\
\hline S. oculatum & Isle of Man, Pool A (125 km) & 5 May 02 & 8 & $\begin{array}{l}\text { VIII } \\
\text { II }\end{array}$ & $\begin{array}{l}6 \\
2\end{array}$ \\
\hline S. oculatum & Isle of Man, Pool B (125 km) & 5 May 02 & 12 & $\begin{array}{c}\text { VIII } \\
\text { IV } \\
\text { II }\end{array}$ & $\begin{array}{l}5 \\
2 \\
5\end{array}$ \\
\hline S. oculatum & Maine: ANP (4500 km) & Aug 04 & 28 & II & 28 \\
\hline S. oculatum & Maine: SML (4750 km) & 15 Aug 02 & 33 & II & 33 \\
\hline S. oculatum & Maine: SML (4750 km) & 18 Aug 03 & 7 & II & 7 \\
\hline S. stylifer & Maine: SML (4750 km) & 18 Aug 03 & 5 & VII & 5 \\
\hline S. stylifer & Maine: SML (4750 km) & 18 Aug 03 & 6 & VII & 6 \\
\hline S. stylifer & Connecticut (5070 km) & 27 Sep 02 & 8 & $\begin{array}{l}\text { VI } \\
\text { VII }\end{array}$ & $\begin{array}{l}1 \\
7\end{array}$ \\
\hline S. stylifer & Maine: SML (4750 km) & 18 Aug 03 & 6 & VII & 6 \\
\hline S. stylifer & Maine: SML (4750 km) & 18 Aug 03 & 5 & VII & 5 \\
\hline S. stylifer & Brazil (9375 km) & 16 Dec 04 & 3 & VII & 3 \\
\hline
\end{tabular}


specific primers and the BigDye terminator kit (Perkin Elmer). Sequences were run on an ABI 3100 automated sequencer.

Sequences generated using a single primer were compared in SeqMan (DNAStar) and ambiguous sites were checked by eye. An alignment of data was per-
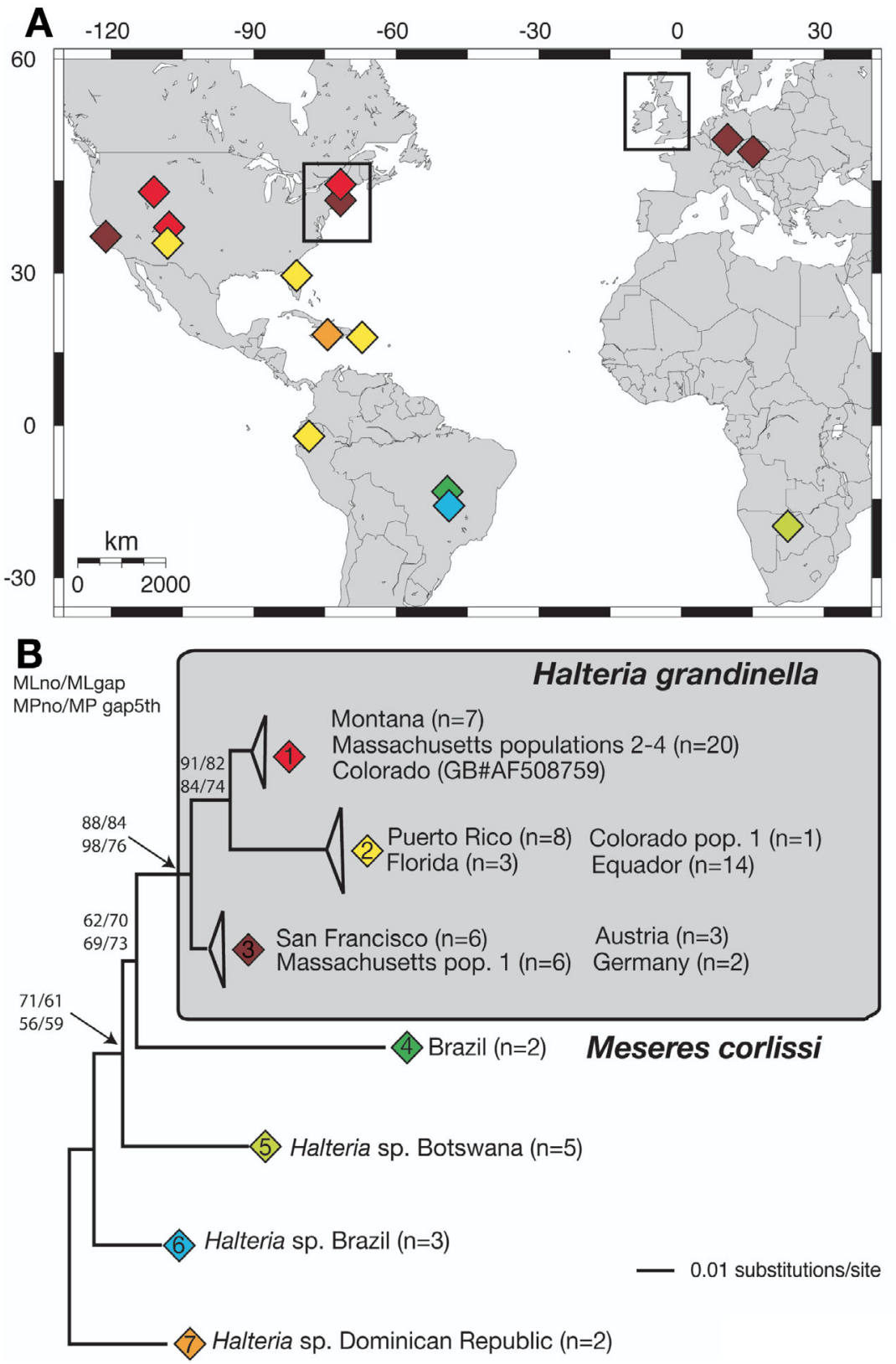

Fig. 1. (A) Locations of Halteria grandinella and its relatives (see Table 1 for description of locations). Colors correspond to the different clades in the H. grandinella genealogy; black insets refer to regions in Fig. 3. (B) Genealogy based on maximum-likelihood analysis of ITS data. Bootstrap values are shown at nodes: upper values are maximum-likelihood with gaps removed (MLno), and maximum-likelihood with gaps included (MLgap); lower values are maximum parsimony with gaps excluded (MPno), and maximum parsimony gaps treated as 5th character (MPgap5th) formed using the Clustal W algorithms (Thompson et al. 1994) as implemented in Megalign (DNAStar). The ITS alignment yielded 512 characters in total and 468 after excluding ambiguously aligned regions.

Genealogical analysis of ITS nucleotide data was performed using the maximum likelihood (ML) and maximum parsimony (MP) algorithms of

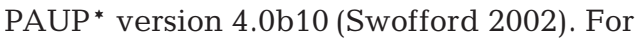
$\mathrm{MP}$, the most parsimonious consensus tree was generated in an exhaustive search with gaps treated as a fifth character or removed. For ML, the most likely consensus tree was built in an heuristic search with gaps removed and with gaps treated as missing data. Modeltest Version 3.06 (Posada \& Crandall 1998) was used to determine an appropriate model for ML analysis as well as to estimate the parameters for the data set. Bootstrap values were calculated using 100 replicates under all models. Percent uncorrected nucleotide divergence was calculated using PAUP* version $4.0 \mathrm{~b} 10$.

\section{RESULTS}

We analyzed variation in the ITS locus in clones from 15 populations of the morphospecies Halteria grandinella and its relatives Halteria spp. (3 distinct morphospecies) and Meseres corlissi from North America, South America, Europe and Africa (Figs. 1 \& 2, Table 1). Genealogical analyses of the resulting sequences reveal 7 distinct clades of sequences $(<2 \%$ divergence within clades). We chose a $2 \%$ cutoff as a starting point, as some authors have suggested that 1 to $2 \%$ rDNA divergence is equivalent to morphospecies designations (Jerome et al. 1996, Shin et al. 2000). In fact, intraclade divergences based on this cutoff are all $\leq 0.5 \%$, while interclade divergences are as high as $7.64 \%$ (Table 3 ). Hence, in contrast to a continuous distribution of diversity among sequences, as would be expected if we had sampled a genetically cohesive cluster of lineages, we find ciliates with identical or nearly identical ITS sequences in disparate locations. For example, Clade 3 contains 17 sequences that diverge on average by $0.25 \%$ and represent populations from both sides of the United States (San Francisco and Massachusetts) and from Europe (Austria and Germany). In 


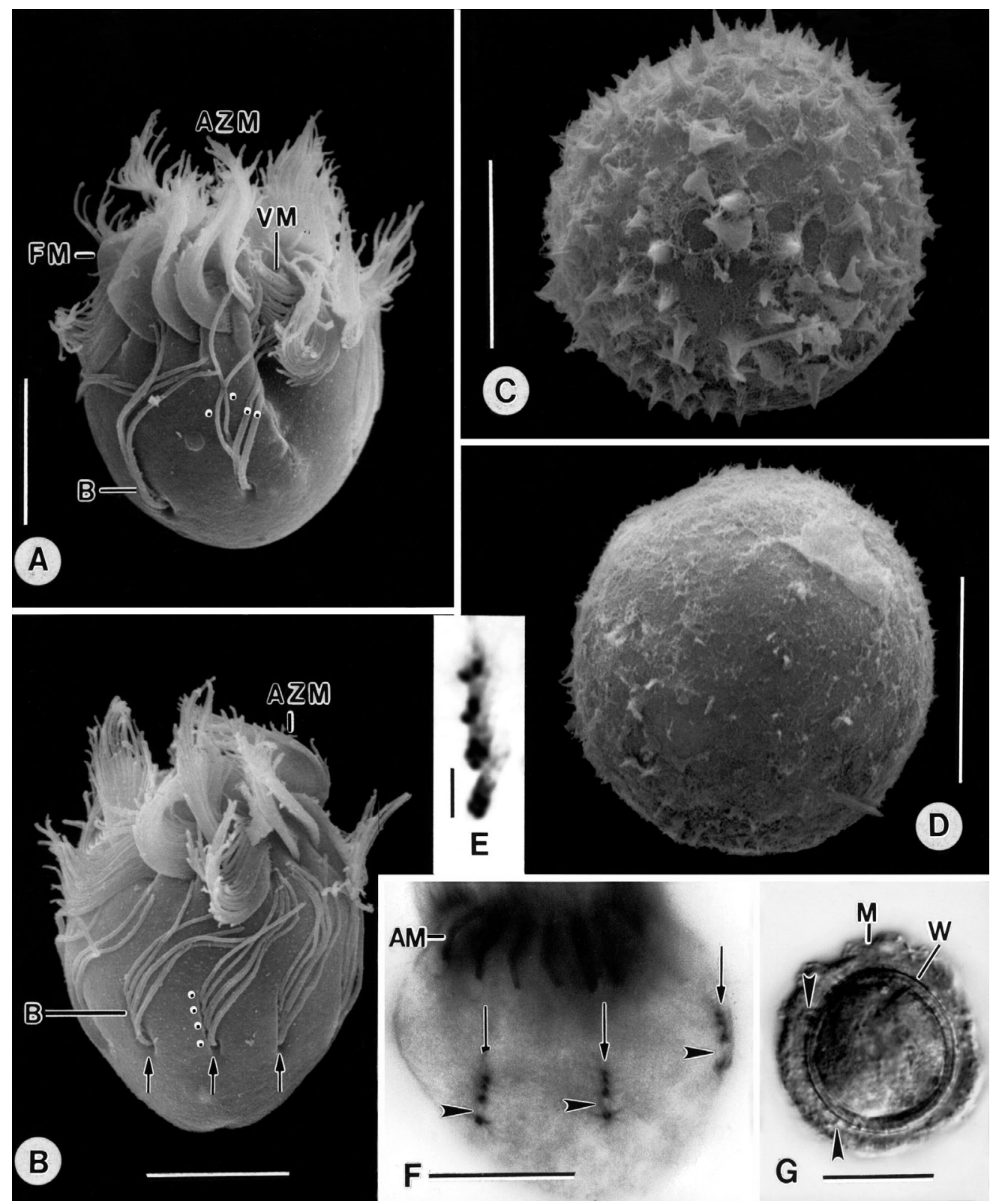

Fig. 2. Halteria populations from (A-C) the Dominican Republic, (D) Austria, and (E-G) Botswana in the scanning electron microscope (A-D), after protargol impregnation $(\mathrm{E}, \mathrm{F})$, and from life $(\mathrm{G})$. $(\mathrm{A}, \mathrm{B})$ Ventral and dorsal overviews, respectively. The general appearance and the basic structure of the bristle rows (arrows) are the same in all populations investigated (Table 1). The bristle rows each consist of 2 single cilia anteriorly and 2 cilia pairs posteriorly (dots). $(C, D, G)$ The 3 populations shown can be distinguished by the resting cysts. The cyst of the Dominican population (C) has conical scales attached to a fibrous mucus layer, while the Austrian specimens (D) have a smooth wall. The Botswanan population has conical scales (G, arrowheads) embedded in a thick, mucus envelope. (E,F) Typically, the jumping bristle rows of Halteria each consist of 4 equidistantly spaced complexes $(\mathrm{B}, \mathrm{F}$, arrows), while the distance is increased between complexes 3 and 4 in the Botswanan specimens (F, arrowheads). AM: adoral membranelles; AZM: adoral zone of membranelles; B: jumping bristles; FM: frontal (collar) membranelles; M: mucus envelope; VM: ventral membranelles; W: cyst wall. Scale bars $=10 \mu \mathrm{m}(\mathrm{A}-\mathrm{D}), 2 \mu \mathrm{m}(\mathrm{E})$, and $20 \mu \mathrm{m}(\mathrm{F}, \mathrm{G})$

contrast, Clade 3 is 2.0 and $3.7 \%$ divergent from Clades 1 and 2 (its closest relatives), respectively.

These analyses demonstrate that at least some Halteria spp. experience high gene flow, as some clades (e.g. 1 to 3) are found across broad geographic areas. For example, sequences obtained from populations in Northampton, Massachusetts (Clade 3) are more similar to sequences from Germany than they are to those 
Table 3. Percent divergence within and between clades of Halteria grandinella and its relatives, calculated using uncorrected distances

\begin{tabular}{|lccccccc|}
\hline Clade $^{\mathrm{a}}$ & 1 & 2 & 3 & 4 & 5 & 6 & 7 \\
\hline 1 & 0.13 & & & & & & \\
2 & 2.93 & 0.25 & & & & & \\
3 & 1.95 & 3.71 & 0.25 & & & & \\
4 & 6.69 & 7.31 & 6.49 & 0.39 & & & \\
5 & 6.05 & 7.64 & 4.88 & 8.22 & 0.20 & & \\
6 & 5.07 & 5.88 & 4.10 & 7.22 & 5.23 & 0.41 & \\
7 & 5.61 & 7.41 & 5.20 & 7.80 & 6.15 & 4.55 & 0.20 \\
a Descriptions of populations/clades refer to Table 1 and Fig. 1 & \\
\hline \multicolumn{7}{l}{} \\
\hline
\end{tabular}

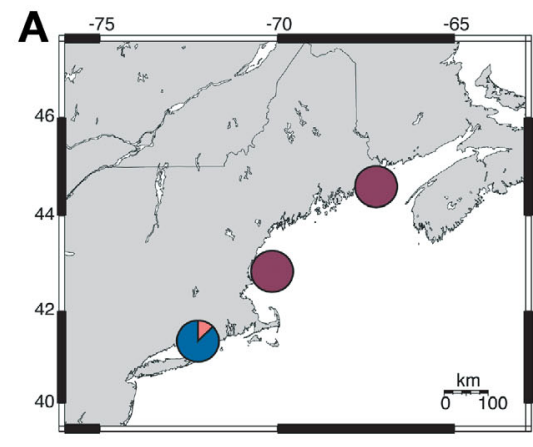

B

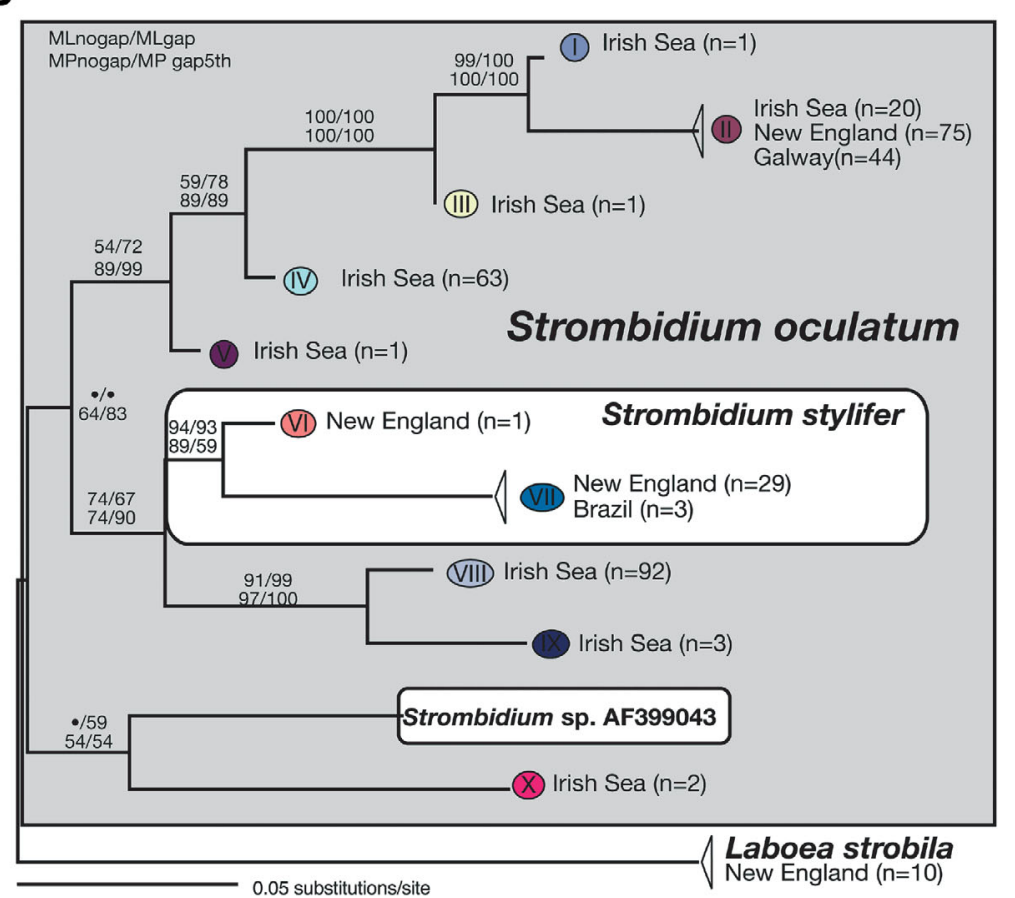

Fig. 3. (A) Map indicating the locations of Strombidium oculatum and $S$. stylifer sampling sites, from which at least 8 clones were sequenced (see Table 2). Only a few clones were sequenced from many pools and although they are included in the genealogy, these populations are not displayed on the map. Colors correspond to the different clades in the $S$. oculatum genealogy. (B) Genealogy based on maximum-likelihood analysis of ITS data (see 'Materials and methods'). The genealogy is rooted with previously published sequences of Laboea strobila. Bootstrap values as in Fig. 1 from nearby Chesterfield, Massachusetts (Clade 1; Fig. 1). While other clades may be geographically isolated (e.g. Clades 4 and 6 were only found in South America and Clade 5 in Africa), substantially more data are required to determine the extent to which gene flow occurs or is limited among locations.

To further assess morphospecies descriptions, protargol staining was carried out on representative Halteria populations from Clades 2, 3, 4, 5 and 7. Consistent with our genealogy, Clades 5 to 7 are morphologically distinct at this more detailed level of microscopy (Table 4). Intriguingly, the Southern Hemisphere clades (4 to 7 ) are present in morphospecies that have spiny cysts, while $H$. grandinella from Europe and North America (Clades 1 to 3) make smooth cysts (Fig. 2C,D, Table 4).

Analysis of the second species cluster, the tide pool morphospecies Strombidium oculatum and S. stylifer, collected over short temporal (tidal) and both small and large spatial scales reveals similar patterns of high genetic diversity, except that considerable variation also exists within populations of these taxa (Figs. $3 \& 4$, Tables $2 \& 5$ ). These species can be distinguished by the habit of $S$. oculatum to encyst with a tidal periodicity, and by a posterior thorn-like projection that is usually present on $S$. stylifer. In $S$. stylifer, the adoral zone extends further down the ventral side than that of $S$. oculatum, and the girdle kinety of $S$. oculatum is closer to the mouth. Both species inhabit similar environments, contain a prominent eyespot, and are mixotrophs, harboring 'slave' chloroplasts derived from green macroalgae (McManus et al. 2004).

Genealogical analyses of 336 clones from Strombidium oculatum and S. stylifer isolated from both sides of the North Atlantic and from the western South Atlantic (coastal Brazil) reveal not 2 but 10 distinct clades (>2\% sequence divergence; Fig. 3). As with Halteria spp., there is evidence of both genetic diversity and high levels of gene flow in $S$. oculatum despite the seemingly restricted habitat of this tide pool ciliate (Fig. 3, Table 2). For example, individuals represented in Clade II are found in both the Irish Sea and on the East Coast of North America. To our 


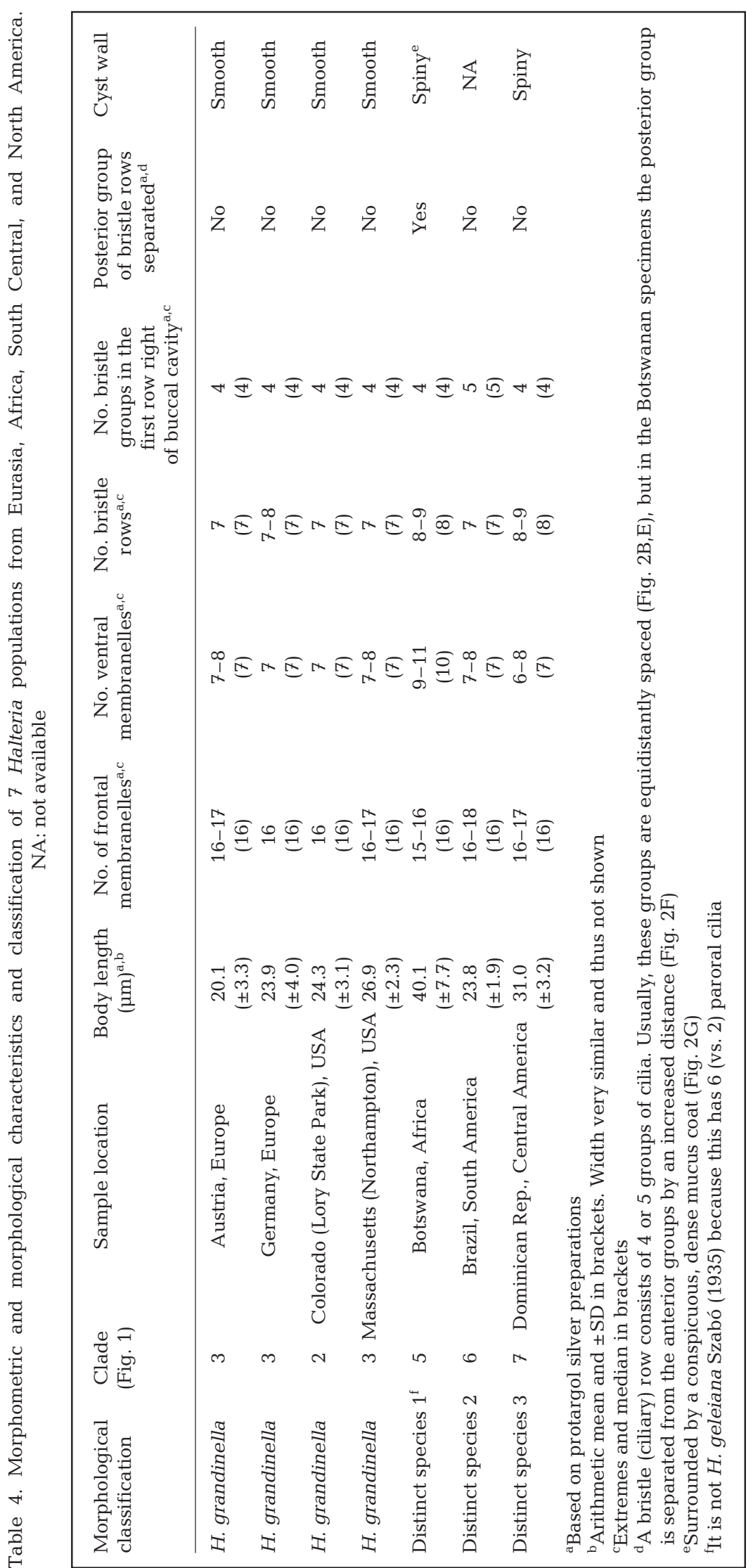

knowledge, $S$. oculatum has never been observed in open waters outside of tide pools, yet identical haplotypes of this morphospecies can be found thousands of kilometers apart on both sides of the North Atlantic Ocean. Moreover, we again find low levels of diversity within clades and high divergence (up to $15.7 \%$ ) between clades (Table 5). Because these ciliates are capable of sexual recombination, the low divergence within clades and high divergence between them is evidence that they are reproductively isolated. Moreover, we find no footprint of recent recombination in the ITS locus (i.e. exchange of linked polymorphisms), indicating that haplotypes are not the result of recent hybridization.

The greatest genetic diversity in Strombidium oculatum is present within the Irish Sea, suggesting that this region may have served as a refugium for $S$. oculatum during the last glaciation. For example, individuals in Clades I to V, and VIII to X all coexist in pools along the Irish Sea, where we sampled most intensively (Table 2). However, our largest sample is from this area: more samples from across the North Atlantic and across different time periods are needed. We found no evidence that cyclical encystment behavior of $S$. oculatum (Montagnes et al. 2002) results in genetically isolated populations. For example, Clades IV, VIII, and IX were all found in a single pool on 2 consecutive low tides in Dublin Bay (on 14 May 2002; Pool 4, Table 2).

Morphospecies designations in Strombidium oculatum and S. stylifer are not consistent with genetic haplotypes. The clades of $S$. oculatum are paraphyletic with respect to $S$. stylifer and a previously characterized Strombidium sp. (GenBank AF399043) isolated from open coastal waters in the western North Atlantic (Fig. 3). We speculate that detailed microscopy will show that this high genetic divergence is matched by fine-scale morphological and/or behavioral variations within $S$. oculatum and $S$. stylifer. 

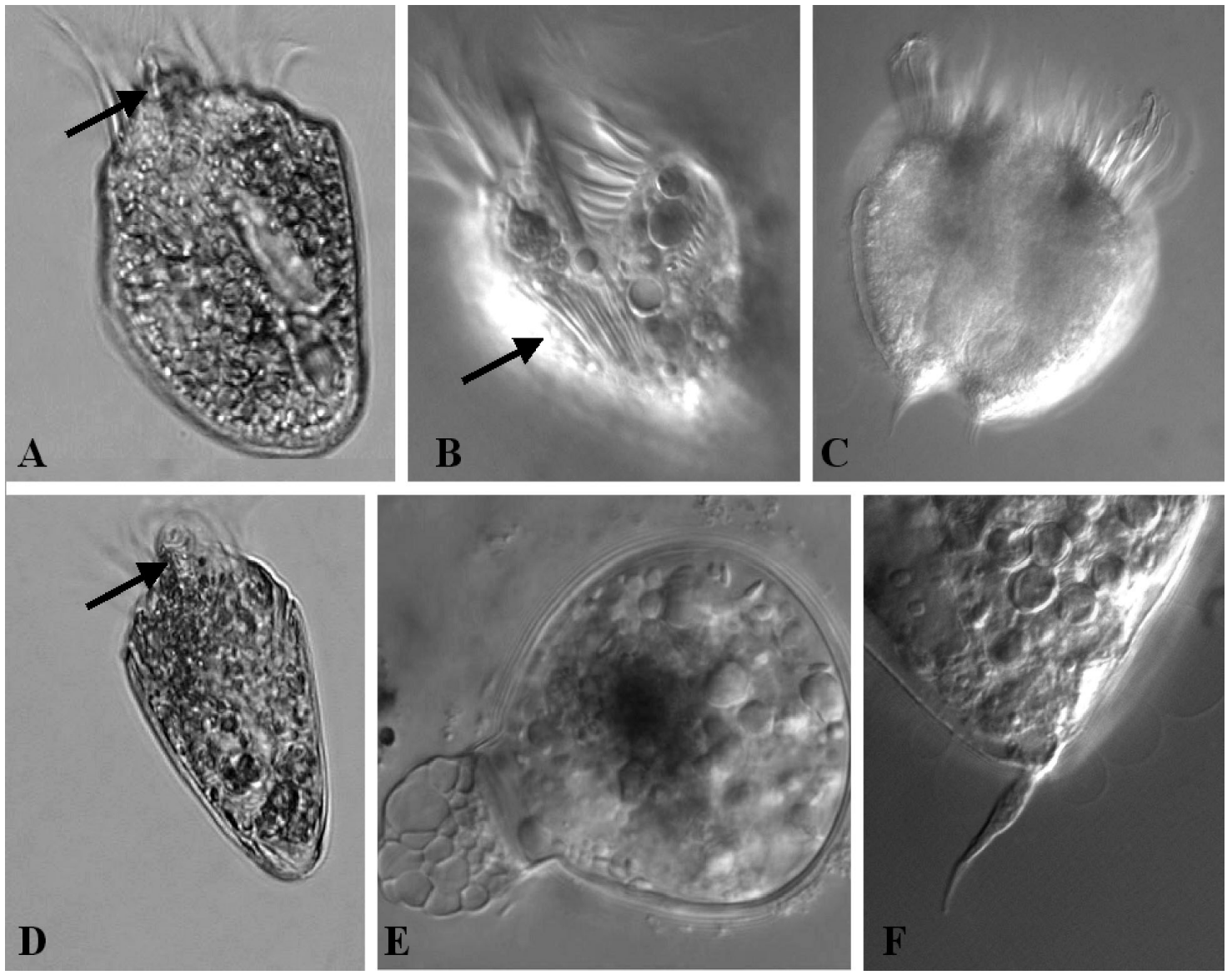

Fig. 4. Morphology of Strombidium oculatum and S. stylifer. (A,D) S. oculatum from live populations sampled in Dublin Bay, Ireland, with arrows showing eyespots. (B) S. stylifer from a culture isolated from Scotland, with arrow showing extrusomes. (C) Conjugating pair of $S$. stylifer from a culture isolated from a tide pool in Scotland. (E) Cyst from a New England $S$. stylifer culture. (F) Closeup of the 'stachel', a posterior thorn-like projection from a culture of $S$. stylifer isolated from Brazil. The ciliates are approximately $65 \mu \mathrm{m}$ in length; the stachel in this case is ca. $10 \mu \mathrm{m}$, but the size and morphology of this structure varies widely

Table 5. Percent divergence within and between Strombidium spp. clades. -: containing only 1 clone. S: Strombidium; L: Laboea. Sampling information from Table 2

\begin{tabular}{|c|c|c|c|c|c|c|c|c|c|c|c|c|}
\hline & $\begin{array}{l}\text { Clade } \\
\text { I }\end{array}$ & $\begin{array}{c}\text { Clade } \\
\text { II }\end{array}$ & $\begin{array}{l}\text { Clade } \\
\text { III }\end{array}$ & $\begin{array}{l}\text { Clade } \\
\text { IV }\end{array}$ & $\begin{array}{l}\text { Clade } \\
\text { V }\end{array}$ & $\begin{array}{l}\text { Clade } \\
\text { VI }\end{array}$ & $\begin{array}{l}\text { Clade } \\
\text { VII }\end{array}$ & $\begin{array}{l}\text { Clade } \\
\text { VIII }\end{array}$ & $\begin{array}{l}\text { Clade } \\
\text { IX }\end{array}$ & S. sp. & $\begin{array}{l}\text { Clade } \\
\text { X }\end{array}$ & L. strobila \\
\hline Clade I & - & & & & & & & & & & & \\
\hline Clade II & 4.48 & 0.18 & & & & & & & & & & \\
\hline Clade III & 2.20 & 5.92 & - & & & & & & & & & \\
\hline Clade IV & 6.78 & 10.59 & 4.59 & 0.07 & & & & & & & & \\
\hline Clade V & 8.02 & 12.59 & 6.03 & 2.90 & - & & & & & & & \\
\hline Clade VI & 12.75 & 13.27 & 11.33 & 9.01 & 7.80 & - & & & & & & \\
\hline Clade VII & 13.66 & 14.20 & 13.06 & 10.75 & 11.85 & 6.31 & 0.23 & & & & & \\
\hline Clade VIII & 15.03 & 14.06 & 13.61 & 11.00 & 8.28 & 7.49 & 11.18 & 0.16 & & & & \\
\hline Clade IX & 13.40 & 12.01 & 11.15 & 6.35 & 9.21 & 9.72 & 11.48 & 4.55 & 1.00 & & & \\
\hline $\begin{array}{l}\text { Strombidium sp. } \\
\text { AF399043 }\end{array}$ & 16.07 & 14.90 & 14.67 & 12.38 & 11.37 & 12.31 & 13.22 & 12.24 & 13.57 & - & & \\
\hline Clade X & 15.72 & 15.48 & 14.15 & 10.57 & 11.33 & 12.75 & 14.68 & 12.07 & 11.63 & 11.39 & 0 & \\
\hline $\begin{array}{l}\text { Laboea strobila } \\
\text { AF399079 }\end{array}$ & 18.72 & 19.01 & 18.13 & 15.57 & 15.39 & 14.89 & 16.39 & 16.22 & 16.87 & 16.14 & 16.26 & - \\
\hline
\end{tabular}




\section{DISCUSSION}

We propose that the ephemeral nature of tide pools and freshwater bodies, at least over evolutionary scales, drives the diversification of these morphospecies due to past periods of isolation (Fig. 5). In the case of Strombidium oculatum and $S$. stylifer, for example, we estimate the divergences in these populations to have been initiated during the Miocene, $\sim 6$ to 20 million yr ago (mya), based on a rate of mutation in the ITS of roughly 0.5 to $1 \%$ /million yr (Bargues et al. 2000, LaJeunesse 2005). Intriguingly, similar divergence times have been estimated for the early diversification of species of symbiotic marine dinoflagellates (LaJeunesse 2005). Our data suggest that tide pool populations became isolated during periods such as the sharp drop in eustatic sea level during the upper Miocene about 10 mya (Haq et al. 1987), which corresponds to the estimate of earliest divergence among our clades. Such an isolation could have occurred due to loss of appropriate habitats and/or extinction of intervening populations. Furthermore, at the last glacial maximum ca. $20000 \mathrm{yr}$ BP, probably all of the rocky shore of New England and much of northern Europe was covered with ice, shorelines were beyond

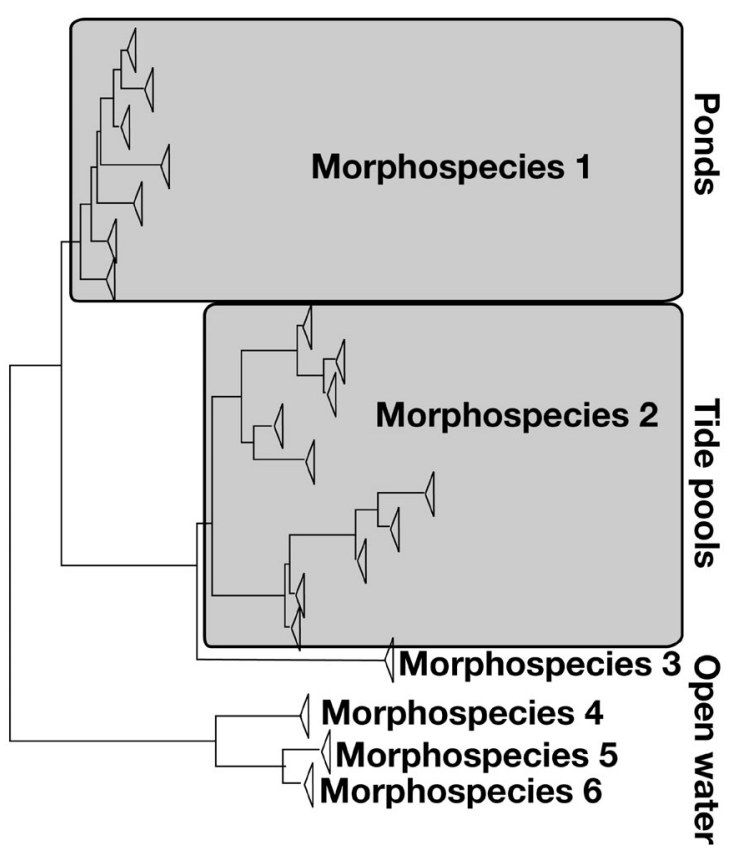

Fig. 5. Hypothesis of interaction of genetic diversity, morphospecies and habitat type. The genetic diversity of ciliate morphospecies appears to vary by habitat type. Ciliate morphospecies in evolutionary unstable habitats, tide pools and freshwater, contain considerable diversity. In contrast, morphospecies in the open ocean, where there have likely been fewer historic barriers to gene flow, contain more limited genetic variation the shelf edges, and tide pool habitats were either nonexistent or minimal (Dyke et al. 2002). Subsequent isolation due to sea level changes and occasional gene flow in ocean currents would re-establish pools through dispersal. Such events, occurring repeatedly over millions of years in both tide pools and freshwater habitats, may have led to periods of isolation that generated distinctive genetic clades.

In this scenario, it is possible that the northeast Atlantic coast, where we see the greatest diversity of Strombidium oculatum haplotypes, served as a refugium in which diversity was preserved during periods of isolation due to sea level changes. Alternatively, the high level of genetic diversity within the Irish Sea could reflect recent gene flow/migration, perhaps even mediated by anthropogenic movement of ships and water. Regardless, the subsequent persistence of genetically isolated Strombidium spp. within tide pools suggests that some form of niche separation has occurred among the genetically distinct ciliates as ecologically identical clades are unlikely to persist over long time periods (Fig. 5).

Support for the idea that the ephemeral nature of habitats (tide pools, ponds) is related to the observed cryptic diversity within Halteria spp. and Strombidium spp. morphospecies comes from comparisons with open water representatives of the same orders of ciliates. Contrary to our observations on Halteria spp. and Strombidium spp., genetic divergence among clones of this same locus is low for previously published spatially and temporally separated populations of the planktonic ciliates Eutintinnus pectinis, Tintinnopsis sp., and Favella ehrenbergii (SnoeyenbosWest et al. 2002). Similarly, the small subunit rDNA sequences are virtually identical in Laboea strobila isolated from the Isle of Man (British Isles) (Agatha et al. 2004), Trieste (Italy) (Agatha et al. 2004) and Connecticut (USA) (Snoeyenbos-West et al. 2002). The low genetic diversity within these planktonic species suggests either that open water ciliates have not been subject to periods of past isolation, or that dominant haplotypes have replaced other genetic variants in this more continuous environment.

Our data indicate that future studies of ciliates from evolutionarily ephemeral habitats should include large sample sizes to test for the presence of cryptic diversity. For example, in our relatively limited sampling of tide pool Strombidium spp., we found 4 haplotypes each represented only a single time, suggesting that there are more rare haplotypes yet to be discovered (Fig. 3). Moreover, measures of abiotic factors and ecological roles may reveal environmental correlates for genetically distinct haplotypes. Finally, as with all single marker studies, additional data from elsewhere in the ciliate genome are required to confirm the 
observed pattern of genetic diversity and to fully assess potential impact of sex/hybridization.

Evidence for greater diversity of eukaryotic microbes in general is beginning to emerge from molecular analyses of diverse lineages. For example, recent analyses of the flagellate genera Ancyromonas, Cafeteria, and Caecitullus from surface waters and deepsea sediments revealed that individual morphospecies can be underlain by diverse genetic entities (Scheckenbach et al. 2005). Furthermore, cryptic species in some planktonic Foraminifera have been observed through DNA analysis, and have subsequently been supported by more detailed studies of morphology and ecology (de Vargas et al. 1999).

In sum, we have shown both high gene flow and high diversity in 2 clades of ciliates from ephemeral environments (Fig. 6). In one of those clades (Strombidium oculatum/S. stylifer), we have also found very high diversity in co-occurring populations. The presence of high genetic diversity concomitant with high gene flow among some populations of $S$. oculatum/ S. stylifer and Halteria spp. suggests that understanding the phylogeography of ciliates, and perhaps protists in general, requires disentangling gene flow and genetic diversity as separate parameters (Fig. 6). Our study is consistent with the observation of cryptic species in the model ciliates Tetrahymena and Paramecium (Nanney 2004), both of which are restricted to freshwater habitats. Hence, it is likely that there are many more species of protists yet to be discovered (Foissner 1999, in press) and that current rates of gene flow may be high for many of these species.
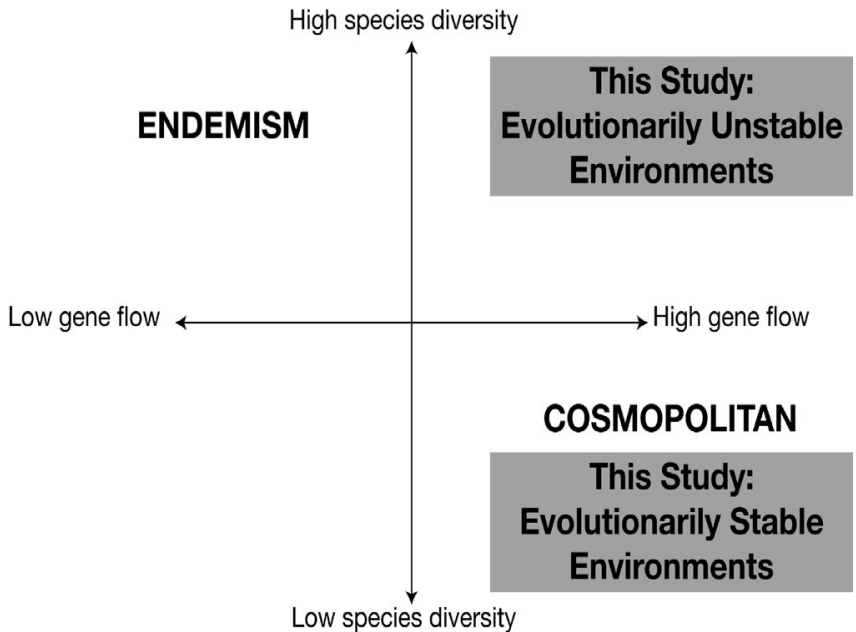

Fig. 6. Revised model of ciliate biogeography. Results from the Halteria grandinella and Strombidium oculatum data occupy the upper right quadrant (high gene flow, high species diversity), results from previously published data on marine ciliates the lower right quadrant
Acknowledgements. This work was supported by the US National Science Foundation (OCE 0221137 and 636458; L.A.K., G.B.M. and O.L.O.S.-W.), the Austrian Science Foundation (FWF project P16796-B06), the Tomlinson Funds from Smith College (K.P., A.G.), and a Fulbright Fellowship (G.B.M.). We thank D. S. Montagnes for his help early in the project with identifications, and the Zoology Department, Trinity College Dublin, Ireland, for use of facilities. Thanks also to S. Agatha (University of Salzburg) for useful discussions; A. Baron (Smith College), who helped in preliminary characterization of some Halteria spp. DNAs; and Micah Dunthorn, who collected the Halteria sample from Ecuador. Finally, we are grateful for the technical assistance of Birgit Peukert. Sequences in this paper can be found under GenBank accession numbers DQ241741 to DQ241757.

\section{LITERATURE CITED}

Agatha S, Struder-Kypke MC, Beran A (2004) Morphologic and genetic variability in the marine planktonic ciliate Laboea strobila Lohmann, 1908 (Ciliophora, Oligotrichia), with notes on its ontogenesis. J Eukaryot Microbiol 51: 267-281

Bargues MD, Marcilla A, Ramsey JM, Dujardin JP, Schofield CJ, Mas-Coma S (2000) Nuclear rDNA-based molecular clock of the evolution of Triatominae (Hemiptera: Reduviidae), vectors of Chagas disease. Mem Inst Oswaldo Cruz 95:567-573

de Vargas C, Norris R, Zaninetti L, Gibb SW, Pawlowski J (1999) Molecular evidence of cryptic speciation in planktonic foraminifers and their relation to oceanic provinces. Proc Natl Acad Sci USA 96:2864-2868

Dyke AS, Andrews JT, Clark PU, England JH, Miller GH, Shaw J, Veillette JJ (2002) The Laurentide and Innuitian ice sheets during the Last Glacial Maximum. Q Sci Rev 21: $9-31$

Fenchel T, Esteban GF, Finlay BJ (1997) Local versus global diversity of microorganisms: cryptic diversity of ciliated protozoa. Oikos 80:220-225

Finlay BJ, Corliss JO, Esteban G, Fenchel T (1996a) Biodiversity at the microbial level: the number of free-living ciliates in the biosphere. Q Rev Biol 71:221-237

Finlay BJ, Esteban GF, Fenchel T (1996b) Global diversity and body size. Nature 383:132-133

Foissner W (1991) Basic light and scanning electron microscopic methods for taxonomic studies of ciliated protozoa. Eur J Protistol 27:313-330

Foissner W (1997) Global soil ciliate (Protozoa, Ciliophora) diversity: a probability-based approach using large sample collections from Africa, Australia and Antarctica. Biodivers Conserv 6:1627-1638

Foissner W (1998) An updated compilation of world soil ciliates (Protozoa, Ciliophora), with ecological notes, new records, and descriptions of new species. Eur J Protistol 34:195-235

Foissner W (1999) Protist diversity: estimates of the nearimponderable. Protist 150:363-368

Foissner W (in press) Biogeography of microorganisms: a brief review emphasizing protists. Endocytobiol Cell Res

Haq BU, Hardenbol J, Vail PR (1987) Chronology of fluctuating sea levels since the Triassic. Science 235:1156-1167

Jerome CA, Simon EM, Lynn DH (1996) Description of Tetrahymena empidokyrea $\mathrm{n}$ sp., a new species in the Tetrahymena pyriformis sibling species complex (Ciliophora, Oligohymenophorea), and an assessment of its phylogenetic position using small-subunit rRNA sequences. Can J Zool (Rev Can Zool) 74:1898-1906 
LaJeunesse TC (2005) 'Species' radiations of symbiotic dinoflagellates in the Atlantic and Indo-Pacific since the Miocene-Pliocene transition. Mol Biol Evol 22:570-581

McManus GB, Zhang H, Lin SJ (2004) Marine planktonic ciliates that prey on macroalgae and enslave their chloroplasts. Limnol Oceanogr 49:308-313

Montagnes DJS, Wilson D, Brooks SJ, Lowe C, Campey M (2002) Cyclical behaviour of the tide-pool ciliate Strombidium oculatum. Aquat Microb Ecol 28:55-68

Nanney DL (2004) No trivial pursuit. BioScience 54:720-721

Posada D, Crandall K (1998) MODELTEST: testing the model of DNA substitution. Bioinformatics 14:817-818

Scheckenbach F, Wylezich C, Weitere M, Hausmann K, Arndt $\mathrm{H}$ (2005) Molecular identity of strains of heterotrophic flagellates isolated from surface waters and deep-sea sediments of the South Atlantic based on SSU rDNA. Aquat Microb Ecol 38:239-247

Shin MK, Hwang UW, Kim W, Wright ADG, Krawczyk C, Lynn DH (2000) Phylogenetic position of the ciliates

Editorial responsibility: John Dolan,

Villefranche-sur-Mer, France
Phacodinium (Order Phacodiniida) and Protocruzia (Subclass Protocruziidia) and systematics of the spirotrich ciliates examined by small subunit ribosomal RNA gene sequences. Eur J Protistol 36:293-302

Snoeyenbos-West OLO, Salcedo T, McManus GB, Katz LA (2002) Insights into the diversity of choreotrich and oligotrich ciliates (Class: Spirotrichea) based on genealogical analyses of multiple loci. Int J Syst Evol Microbiol 52: 1901-1913

Swofford D (2002) PAUP*. Phylogenetic analysis using parsimony ( ${ }^{*}$ and other methods). Sinauer Associates, Sunderland, MA

Szabó M (1935) Neuere Beiträge zur Kenntnis der Gattung Halteria (Protozoa, Ciliata). Arch Protistenkd 86:307-317

Thompson JD, Higgins DG, Gibson TJ (1994) Clustal-Wimproving the sensitivity of progressive multiple sequence alignment through sequence weighting, position-specific gap penalties and weight matrix choice. Nucleic Acids Res 22:4673-4680

Submitted: July 25, 2005; Accepted: October 7, 2005

Proofs received from author(s): November 2, 2005 